\title{
Significance of Oxygen Isotope Variations in the Cr-Poor Megacryst Suite
}

Schulze, D.J. ${ }^{1}$, Valley, J.W. ${ }^{2}$, Bell, D.R. ${ }^{3}$, Spicuzza, M. ${ }^{2}$

1. Department of Geology, University of Toronto, Erindale College, Mississauga, Ontario, Canada L5L 1C6

2. Department of Geology and Geophysics, University of Wisconsin, Madison, Wisconsin, USA 53706

3. Geophysical Laboratory, Carnegie Institution of Washington, Washington, D.C., USA, 20015 and Department of Geological Sciences, University of Cape Town, Rondebosch 7700, South Africa

Oxygen isotope studies of basalts and ultramafic xenoliths have provided constraints on the origin and evolution of Earth's mantle. Recent advances using laser fluorination (LF) analysis, however, have shown that many of the complexities and anomalies identified in some of the earlier studies using conventional fluorination methods are artifacts of analytical techniques and/or contamination. The oxygen isotope geochemistry of the upper mantle, as revealed by LF studies of peridotite xenoliths and phenocrysts in oceanic basalts, is much less complex than previously recognized (e.g. Mattey et al., 1994a, b). The real oxygen isotope anomalies (confirmed by LF) that do exist in some mantle materials, such as certain eclogites (Jacob et al., 1994; Mattey et al., 1994a) and EM2 basalts (Eiler et al., 1997), are thus more highly significant than might have been appreciated in the past.

Using LF, we have studied the oxygen isotope composition of Cr-poor megacrysts from kimberlite, which are high-pressure crystallization products of their host kimberlite or related magmas (Smith et al., 1995). High equilibration temperatures of $\mathrm{Cr}$-poor megacrysts (typically $1000-1400^{\circ} \mathrm{C}$ ) indicate that oxygen isotope fractionation between megacrysts and parent liquid is minimal. The oxygen isotope signatures of the megacrysts, therefore, reflect those of the deep source rocks of the kimberlite parent magma (asthenosphere or deep lithosphere), material of deeper origin than most xenoliths sampled by kimberlite on its rise to the surface.

We have determined the oxygen isotope composition of 120 Cr-poor garnet megacrysts from 22 Group I kimberlites in southern Africa, North America, Australia and Greenland and from 4 Group II kimberlites from southern Africa. For purposes of comparison we have also analyzed garnets from 25 peridotites from kimberlites in North America and South Africa, and from 16 eclogites, mostly coesite-bearing varieties from South Africa.

Mean values of oxygen isotope compositions of 36 megacrysts from 11 Group I kimberlites in North America and 45 megacrysts from 9 South African Group I kimberlites are indistinguishable, with values of $5.26 \% \sigma_{\text {v-smow }}$ (standard deviation $(\sigma)=0.16$, standard error $($ S.E. $)=0.03$ ) and $5.31 \% o_{\text {v-smow }}(\sigma=$ 0.14 , S.E. $=0.02$ ), respectively (Fig. 1). The North American data appear to have a bimodal distribution and the southern African megacryst data display a negative skewness. Six garnet megacrysts from Pine Creek, Australia have a mean $\delta^{18} \mathrm{O}$ value of $5.25 \% \sigma_{\mathrm{V} \text {-SMow }}(\sigma=0.05$, S.E. $=0.02)$, and two megacryst garnets from West Greenland have a mean value of $5.29 \%$. In contrast, 31 garnet megacrysts from four Group II kimberlites in southern Africa are enriched in ${ }^{18} \mathrm{O}$ (mean $\delta^{18} \mathrm{O}_{\mathrm{vSMOw}}=5.58 \%$, $\sigma=0.15$, S.E. $=0.02$ ).

Although the first order observations are the relative homogeneity of Group I garnet megacrysts, worldwide, and that Group II garnet megacrysts are significantly different from the Group I suite, local 
inhomogeneities appear to exist in both groups. For example, two populations exist in the Group II kimberlites. For Lace and Driekoppies the mean is $\delta^{18} \mathrm{O}_{\mathrm{vSMOw}}=5.52 \%$ o, $\sigma=0.09$, S.E. $=0.02$ and the mean for Monteleo and Dokolwayo is $\delta^{18} \mathrm{O}_{\mathrm{vSMow}}=5.68 \%, \sigma=0.16, \mathrm{~S} . \mathrm{E} .=0.05$, which do not overlap at the $95 \%$ confidence interval. Similarly, some Group I garnet populations have restricted, non-overlapping ranges in $\delta^{18} \mathrm{O}$ (e.g., Iron Mt., Wyoming garnets are in the range $5.05-5.26 \%$, whereas Kelsey Lake, Colorado garnets are in the range 5.29-5.46\%o). Although a homogeneous source is suggested by such populations with small ranges that correspond to analytical uncertainty in the standard $(\sigma \approx 0.07)$, other populations with ranges that significantly exceed analytical uncertainty appear to represent parent magma derivation from inhomogeneous sources. Large ranges in $\delta^{18} \mathrm{O}$ are found at Hamilton Branch, Kentucky (4.96-5.37\%o), Sloan, Colorado (5.02-5.41\%o), Jagersfontein, S. Africa (4.96-5.43\%o) and Group II Monteleo, S. Africa (5.36-5.92\%o).

Garnets from 25 peridotite xenoliths from kimberlites in North America and South Africa have a mean value of $\delta^{18} \mathrm{O}_{\text {vSMOw }}=5.15 \%, \sigma=0.17$, S.E. $=0.03$. Values of $\delta^{18} \mathrm{O}_{\text {vSMOw }}$ for garnets from 16 eclogites from Southern Africa are quite variable and in the wide range $3.42-7.25 \%$. Within this group, eight Group I coesite-bearing eclogites from the Roberts Victor Mine are in the range 5.32 - 6.84\%o, with a mean value of $5.96 \%$, $\sigma=0.44$, S.E. $=0.16$.

These data show that the oxygen isotope signatures of Cr-poor garnet megacrysts from Group I kimberlites, world-wide (mean value of $5.28 \% o_{\mathrm{vsmow}}$ ), are in general remarkably uniform, similar to data for garnet peridotites (this study and Mattey, 1994a), and significantly different from those of Group II kimberlites. The small positive $\delta^{18}$ Oga-ol value of approximately 0.1\%o (Mattey et al., 1994a) indicates that the megacryst garnet values are equivalent to the average oxygen isotope composition of olivines from lithosphere peridotites $\left(\delta^{18} \mathrm{O}_{\text {vsmow }}=5.19+/-0.26 \%\right.$, Mattey et al., 1994b). Eiler et al. (1997) have reported similar $\delta^{18} \mathrm{O}$ values for olivines from most mid-ocean ridge and ocean island basalts (in the range $5.0-5.4 \%$ ). Thus the bulk of asthenospheric and lithospheric mantle peridotite is apparently uniform in oxygen isotope composition on a regional scale.

Our data are consistent with derivation of Group I kimberlite magmas from lithospheric mantle having approximately "normal" oxygen isotope composition, with no detectable involvement of subducted crustal material. Smith et al. (1995) suggested that this source corresponds to the HIMU reservoir. The fact that olivines phenocrysts in HIMU basalts have $\delta^{18} \mathrm{O}$ values that range from "normal" to slightly low (4.92-5.22\%o, mean $=5.03, \sigma=0.11$; Eiler et al., 1997) and our Group I data are bimodal or negatively skewed (Fig. 1) is consistent with a HIMU source for the megacrysts.

Anomalously high $\delta^{18} \mathrm{O}$ values, similar to those of the Group II garnet megacrysts have been documented in oceanic regions in olivine phenocrysts from EM2 ocean island basalts, which have $\delta^{18} \mathrm{O}_{\text {vSMow }}$ values of $5.6 \%$ o, $\sigma=0.21, \mathrm{SE}=0.06$, (Eiler et al., 1997). The elevated $\delta^{18} \mathrm{O}$ of the EM2 basalts is thought to reflect bulk incorporation of subducted pelagic and/or terrigenous sediments in the mantle source of these basalts (Eiler et al., 1997).

An equivalent source of subducted metasediments with high $\delta^{18} \mathrm{O}$ values that might, through partial melting, contribute to the anomalous oxygen isotope signature of the source of the Group II megacrysts is not evident in the mantle xenolith population. Elevated $\delta^{18} \mathrm{O}$ values are known, however, from Group I eclogite xenoliths from kimberlites, a characteristic that, in part, has lead to interpretation of these eclogites as subducted altered oceanic crust. Oxygen isotope values of garnets from xenoliths of coesite eclogites from Roberts Victor Mine (considered to represent subducted ocean floor basaltic rocks that have not undergone partial melting - Schulze and Helmstaedt, 1988) are in the range 5.32 $6.84 \% 0_{\text {vsMow }}$, averaging $5.96 \%$. Although bulk assimilation of such eclogite during melting could satisfy the oxygen isotope constraints of Group II kimberlites, it does not explain Group II kimberlite minor and trace element composition, nor it readily evident why only eclogite with elevated $\delta^{18} \mathrm{O}$ is 
incorporated. More likely is the involvement of subducted metasediments enriched in ${ }^{18} \mathrm{O}$ (despite their absence in xenolith populations), whether through bulk assimilation or by metasomatic enrichment of depleted lithospheric peridotite by magmas or fluids derived from such sediments.

\section{References}

Eiler, J.M., Farley, K.A., Valley, J.W., Hauri, E., Craig, H., Hart, S.R., and Stolper, E.M., 1997, Oxygen isotope variations in ocean island basalt phenocrysts, Geochim. Cosmochim. Acta, v. 61, pp. 2281-2293.

Jacob, D., Jagoutz, E., Lowry, D., Mattey, D., and Kudrjavtseva, G., 1994, Diamondiferous eclogites from Siberia: Remnants of Archean oceanic crust, Geochim. Cosmochim. Acta, v. 58, pp. 5191-5207.

Mattey, D.P., Lowry, D., Macpherson, C.G.', and Chazot, G., 1994a, Oxygen isotope composition of mantle minerals by laser fluorination analysis: homogeneity in peridotites, heterogeneity in eclogites, Min. Mag., v. 58A, pp. 537-574.

Mattey, D., Lowry, D., and Macpherson, C., 1994b, Oxygen isotope composition of mantle peridotite, Earth Planet. Sci. Letters, v. 128, pp. 231-241.

Schulze, D.J., and Helmstaedt, H., 1987, Coesite-sanidine eclogites from kimberlite: Products of mantle fractionation or subduction?, J. Geol., v. 96, pp. 435-443.

Smith, C.B., Schulze, D.J., Bell, D. and Viljoen, K.S., 1995, Bearing of the subcalcic, Cr-poor megacryst suite on kimberlite petrogenesis and lithosphere structure, Abstr. Sixth Int. Kimb. Conf., Russia, pp. 546-548.

\section{Cr-poor Garnet Megacrysts}
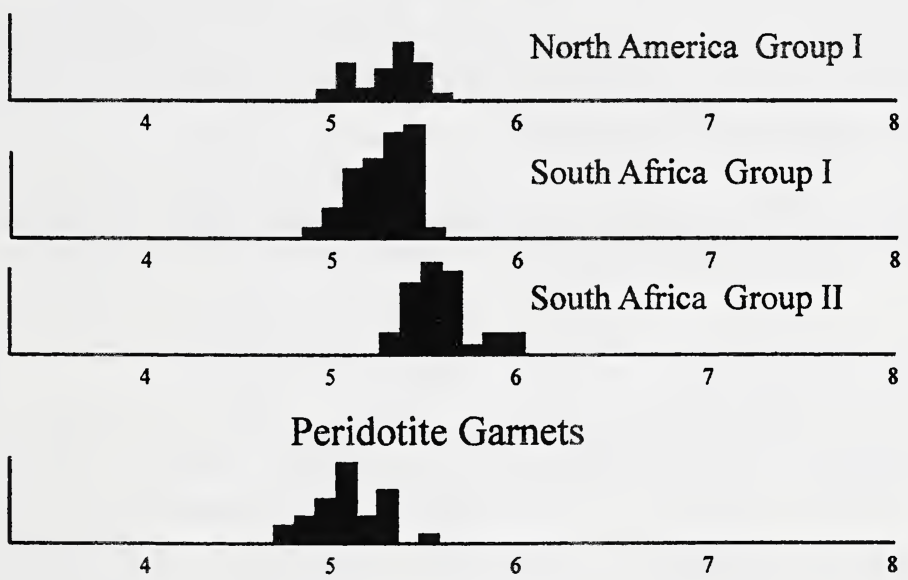

Eclogite Garnets

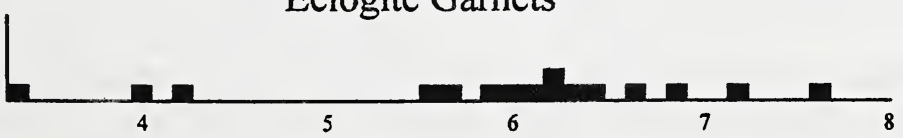

$\delta 180 \%_{\text {vsmow }}$

Fig. 1 Oxygen isotope composition of mantle garnets 